\title{
Neural Transcription Factors: from Embryos to Neural Stem Cells
}

\author{
Hyun-Kyung Lee, Hyun-Shik Lee*, and Sally A. Moody ${ }^{1, *}$
}

The early steps of neural development in the vertebrate embryo are regulated by sets of transcription factors that control the induction of proliferative, pluripotent neural precursors, the expansion of neural plate stem cells, and their transition to differentiating neural progenitors. These early events are critical for producing a pool of multipotent cells capable of giving rise to the multitude of neurons and glia that form the central nervous system. In this review we summarize findings from gain- and loss-of-function studies in embryos that detail the gene regulatory network responsible for these early events. We discuss whether this information is likely to be similar in mammalian embryonic and induced pluripotent stem cells that are cultured according to protocols designed to produce neurons. The similarities and differences between the embryo and stem cells may provide important guidance to stem cell protocols designed to create immature neural cells for therapeutic uses.

\section{INTRODUCTION}

Understanding how the vertebrate nervous system develops from the embryonic ectoderm has been one of the most intensely investigated developmental processes. The process of "neural induction" was discovered by Hans Spemann and Hilde Mangold; when dorsal mesoderm was transplanted adjacent to ventral ectoderm that normally would give rise to skin instead it formed a neural tube (Spemann and Mangold, 1923, reprinted 2001). This result was interpreted to mean that dorsal mesoderm releases a signaling factor that converts the adjacent ectoderm into neural tissue. While the identity of this signal was sought for decades, only in recent years have we come to appreciate the signaling and transcription factors that mediate neural induction and control

ABRC, School of Life Sciences, BK21 Plus KNU Creative BioReserach Group, Kyungpook National University, Daegu 702-702, Korea, ${ }^{1}$ Department of Anatomy and Regenerative Biology, The George Washington University, School of Medicine and Health Sciences, N.W., Washington, D.C., 20037, USA

*Correspondence: leeh@knu.ac.kr (HSL); samoody@gwu.edu (SM)

Received 7 August, 2014; accepted 10 August, 2014; published online 18 September, 2014

Keywords: Foxd4, neural cell fate, neural induction, neural plate stem cells, neural progenitor cells neural differentiation. Recently it has been possible to place these factors in a gene regulatory network that controls the progression of cells from newly induced neural precursors, to proliferative, multipotent neural plate stem cells, to specified neural progenitors. These early steps of neural development are critical for producing a pool of multipotent cells that later give rise to the multitude of neurons and glia in the central nervous system that have diverse and distinct functions, and are selectively affected in a number of human neurodegenerative diseases.

Research to produce a population of cells in vitro that recapitulate the differentiated progeny seen in the intact nervous system has defined a "neural stem cell" (NSC), which is a self-renewing cell whose progeny can produce neurons, oligodendrocytes and astrocytes (Fujita, 2003). In the embryonic neural tube these cells reside in the ventricular zone (or subventricular zone in the developing cerebral cortex), and in both the embryo and in NSC cultures, these cells are activated to produce new progeny by the integration of a number of signaling pathways, such as Sonic Hedgehog, BMP, Wnt/ßCatenin, Notch, and FGF (Fig. 1; Brault et al., 2001; Dahmane et al., 2001; Kalani et al., 2008; Mizutani et al., 2007; Ohtsuka et al., 2001; Palma and Ruiz i Altaba, 2004; Zechner et al., 2003). In both the embryo and in NSC cultures, the self-renewal ability of these cells is regulated by numerous transcription factors, including Hes, Sox, Bmi1, Tlx, and Gli proteins (Fig. 1; Ahmed et al., 2009; Bylund et al., 2003; Collignon et al., 1996; Fuccillo et al., 2006; Gaiano et al., 2000; Hatakeyama et al., 2004; Ishibashi et al., 1995; Miyagi et al., 2008; Molofsky et al., 2005; Palma and Ruiz i Altaba, 2004; Sun et al., 2007; Wood and Episkopou, 1999). The recognition of this cell has inspired numerous researchers to develop new culturing approaches to obtain specific kinds of neurons or glia for therapeutic purposes, such as striatal neurons for Huntington's disease and dopamine neurons for Parkinson's disease. While there has been much success (e.g., reviewed in Chan et al., 2014; Ross and Akimov, 2014), the potential presence of pluripotent stem cells in these cultures remains a concern because they might cause tumors if transplanted into patients.

Therefore, in this review we will focus on what we know about the functions of the signaling and transcriptional factors that control the earliest steps in neural development in the vertebrate embryo. These are the steps that control commitment to a neural fate, proliferation of immature cells, and initiation of differentiation. If we can determine whether the molecular interactions that occur in the embryo to regulate how cells initially become committed to a neural fate are similarly employed when embry- 


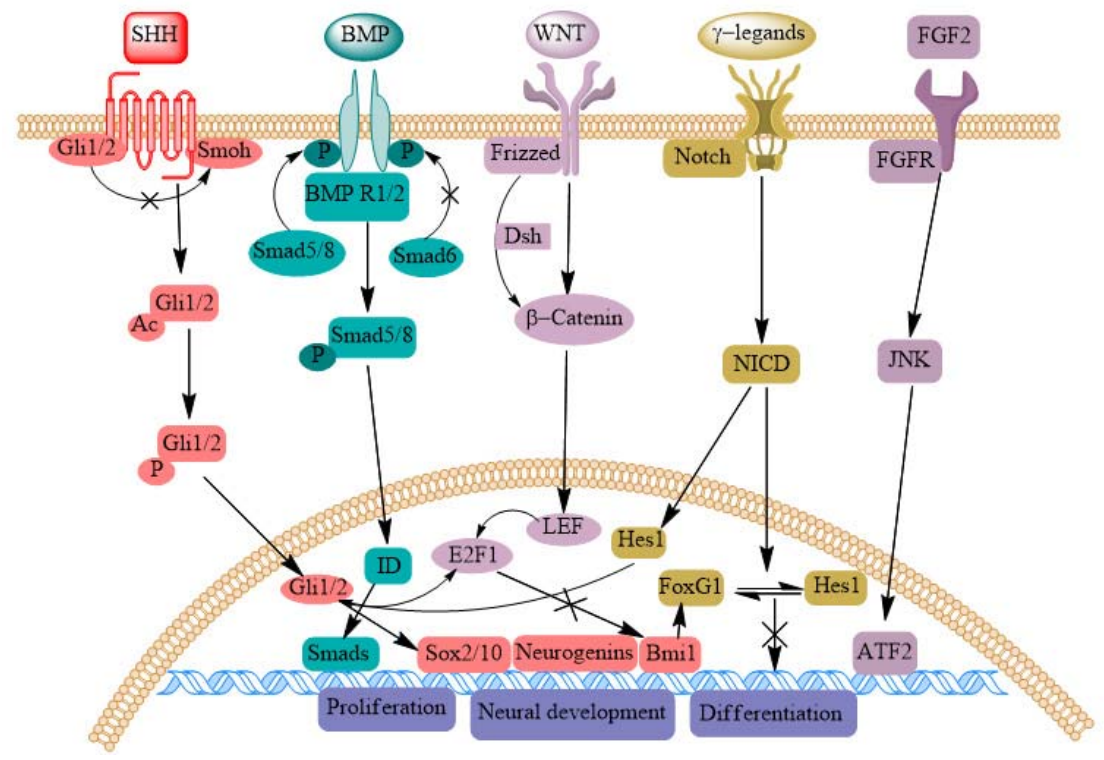

Fig. 1. A schematic representation of main signaling pathways involved in NTFs development during embryogenesis. Five major signaling pathways including SHH, BMP, WNT, Notch ligands and FGF2, together crosstalk is represented. SHH ligand relieves the constitutive repression of the seven-pass receptor smoothened (SMO) by the modulation of the GLI transcriptional activators Gli1/2. Extracellular regulation of BMP signaling BMP induces the dimerization and then tetramerization of BMP receptors, leading to phosphorylation of the cytoplasmic signal transducer SMAD. WNT signaling activates $\beta$-catenin by modulating Frizzed and Dsh. Transcription factor LEF is required for enhancing of E2F1, consequently block Bmi1. The Notch and FGF2 signaling pathways have been implicated in regulating the neural differentiation and development. Notch interacts with NICD and mediates the effect of Hes1 and Gli/12. FGF2 activates JNK through binding with FGFR receptors, thus activating ATF2 regulatory mechanisms in neural development.

onic stem cells (ESCs) and induced pluripotent stem cells (iPSCs) are differentiated into NSCs, we will be able to eliminate tumorigenic cells. Therefore, we will relate the findings from embryos to studies of cultured mammalian stem cells in expectation that the knowledge gained from the embryo will significantly enhance in vitro stem cell approaches and thereby yield transplantable neural precursors for regenerative applications.

\section{NEURAL INDUCTIVE SIGNALING}

The vertebrate neural ectoderm forms on the dorsal side of the embryo in response to signals from the adjacent dorsal mesoderm, which is called the "Organizer" in frog and fish and the "Node" in chick and mouse (reviewed in De Robertis and Kuroda, 2004; Itoh and Sokol, 2007; Levine and Brivanlou, 2007; Moody et al., 2013; Rogers et al., 2009a; Stern, 2005). Small diffusible proteins that are secreted from the Organizer bind to either BMP or Wnt ligands and prevent them from activating their receptors in the adjacent ectoderm. Embryonic ectodermal cells become epidermis (skin) in the presence of BMPs and Wnts and become neural ectodermal (NE) precursors in their absence (Fig. 1). The newly induced NE precursors express a large number of neural transcription factors (nTFs), including members of the Fox, Sox, Zic and Irx families, that are co-expressed in broad overlapping domains. Some of these factors regulate the competence of the NE precursors to respond to neural inducing signals and cause the newly induced neural cells to become refractory to BMP and Wnt signals (Moody et al., 2013; Rogers et al., 2009a; Sasai, 1998).

FGF signaling is another important pathway that facilitates neural induction (Fig. 1; Streit et al., 1998; 2000; Wilson et al.,
2000). One of the downstream effectors of the FGF neural promoting activity is a protein called Churchill (Churc), which upregulates early neural genes and down-regulates early mesodermal genes (Sheng et al., 2003). Its activity is mediated, at least in part, by a Smad-interacting protein called Sip1 (Verschueren et al., 1999). Sip1 is expressed in the dorsal ectoderm at the time that neural induction is occurring, converts naïve ectoderm to neural ectoderm, represses mesoderm genes and inhibits BMP signaling (Eisaki et al., 2000; Nitta et al., 2004; 2007). The FGF-mediated switch from mesodermal to neural fates also is regulated by a pluripotency transcription factor, POU91/Oct4, upstream of Churc and Sip1(Snir et al., 2006). Thus, these factors appear to be activated at the time cells are switching off a pluripotency program.

Adding neural inducing factors to ESC or iPSC cultures also directs these cells to become NE precursors (also called primitive neural stem cells) (Devine et al., 2011; Tropepe et al., 2001). Some of the cells in ESC cultures secrete BMPs and Wnts, and maintaining NE precursors depends on inhibiting these signals (Tropepe et al., 2001), just as in the embryo. Maintaining the expression of SOX1 in human ESC and iPSC cultures also requires continuous down-regulation of BMP signaling (Chaddah et al., 2012; Neely et al., 2012). However, unlike in the embryo, FGF signaling inhibits human ESCs from forming neural tissues, at least under some culture conditions (Greber et al., 2011). It is not clear whether this means that FGF signals have different effects in embryos versus ESCs, or whether FGF signaling acts to promote mesoderm formation under these culture conditions. It will be very informative to more precisely determine the roles of FGF signaling in neural induction of cultured stem cells. To our 
knowledge, no studies have been published regarding Churc function in stem cell cultures. But, SIP1 plays a key role in the decision between neural ectoderm and mesendoderm in human ESCs and in mouse epiblast stem cells (Chng et al., 2010). Thus, the evidence so far suggests that the induction of the NE precursor state in ESC and iPSC cultures relies upon some of the same signaling factors as in the embryo. Further study of the timing and effectiveness of these factors in both embryos and stem cell cultures may reveal how to drive cells towards a stabilized neural fate and prevent the formation of unwanted lineages.

Transitioning to neural plate stem and neural progenitor cells

Once the neural ectoderm is induced and the nTFs are expressed, the tissue continues to be exposed to both BMP and Wnt signals from the surrounding mesoderm and ectoderm. It has been proposed that some of the earliest expressed nTFs somehow stabilize the neural fate program, and thereby prevent cells from reverting to a non-neural fate (Sasai, 1998). Since several of the nTF genes can be directly repressed by BMP-regulated transcription factors (Rogers et al., 2008; Taylor et al., 2006), stabilizing a cell's commitment to a neural fate is important as the signaling environment changes in the embryo. One such factor is Zic1, which causes the embryonic ectoderm to be more sensitive to neural inductive signals (Kuo et al., 1998). To date, the mechanism by which this occurs has not been defined, but perhaps Zic1 attenuates some aspect of BMP or Wnt signaling. In fact, there is evidence for this for many of the other nTFs. Gmnn and Irx1/Xiro1 reduce Bmp4 mRNA levels when ectopically expressed in epidermal domains (Glavic et al., 2001; Gomez-Skarmeta et al., 2001; Kroll et al., 1998). Sox3 down-regulates the expression of the BMP target, Vent2, which is required for epidermis formation (Rogers et al., 2008; 2009b). Foxd4 down-regulates the expression of several genes in the BMP pathway, including their epidermal gene targets, and also reduces the nuclear localization of the phosphorylated SMADs that are the effectors of BMP signaling (Yan et al., 2009; 2010). Sox11 interacts with the MAP kinase NLK to antagonize Wnt signaling by phosphorylating the TCF//3catenin complex (Hyodo-Miura et al., 2002). Ectopic expression of Foxd 4 mRNA in the epidermal lineage, which is a field of high BMPMnt expression, induces several other nTFs in presumptive epidermal cells, indirectly indicating that the BMP and/or Wnt pathways have been repressed (Yan et al., 2009). In fact, we recently found that mouse Foxd4 has the same effects in Xenopus embryos, indicating conservation of this protein's function (unpublished).

These studies in embryos demonstrate that the combined anti-BMP and anti-Wnt activities of several of the earliest expressed nTFs maintain a permissive neural ectoderm environment by dampening the effects of inhibitory BMP and Wnt signals that persist in the embryo after neural induction. Maintenance of a BMP/Wnt-free environment effectively stabilizes the neural fate of the NE precursors, which allows them to transition into neural plate stem cells and prevents them from converting back to a non-neural state. To our knowledge, the roles of these early nTFs in stabilizing neural fates in mammalian ESC cultures have not been explored. We hypothesize that nTFs have a role because maintaining NE precursors depends on inhibiting BMP and Wnt signals (Tropepe et al., 2001), and maintaining the expression of SOX1, another nTF, in human ESC and IPSC cultures requires continuous down-regulation of BMP signaling (Chaddah et al., 2012; Neely et al., 2012). Thus, the maintenance of the NE precursor state in ESC and iPSC cultures may rely upon some of the same signaling and transcription factors as in the embryo.

\section{Expansion of neural plate stem cells}

Once the neural ectoderm has been induced, the cells become highly proliferative and take on a columnar shape, thus forming the neural plate, a morphologically distinct domain that will give rise to the central nervous system. Numerous experiments in embryos show that when the level of each nTF is experimentally increased in NE precursors the neural plate is expanded. This phenotype may occur because the nTFs have broadened the domain in which BMP signaling is repressed, as described above. However, neural plate expansion also appears to result from the ability of some nTFs to promote the proliferation of neural plate stem cells, and/or delay their differentiation into neural progenitors. For example, in Xenopus embryos, Gmnn maintains NE precursors in a proliferative state by modulating interactions between the SWI/SNF complex and the bHLH transcription factors that promote neural differentiation (Seo and Kroll, 2006; Seo et al., 2005). Foxd4 also increases the number of proliferating cells, expands markers of immature neural ectoderm, and down-regulates $b H L H$ neural differentiation genes (Moody et al., 2013; Sullivan et al., 2001). Interestingly, Gmnn and Foxd4 are down-regulated as neural plate stem cells exit the cell cycle and differentiate into neural progenitors (Kroll et al., 1998; Sullivan et al., 2001), indicating that their activities must be suppressed for neural differentiation to proceed. Zic2 also represses $b H L H$ neural differentiation genes and counteracts the formation of extra neurons when $b H L H$ genes are ectopically expressed in the epidermis (Brewster et al., 1998). These studies indicate that Gmnn, Foxd4 and Zic2 cause neural plate expansion by promoting NE precursor and neural stem cell proliferation and delaying the bHLH-mediated establishment of differentiating neural progenitors.

Other nTFs appear to promote the transition of neural plate stem cells to neural progenitor cells, a process that requires cells to exit the cell cycle and initiate $b H L H$ neural differentiation gene expression (Imayoshi and Kageyama, 2014). In several animals, SoxB1 family members (Sox1, Sox2, Sox3) maintain neural stem populations and must be down-regulated for neural progenitor differentiation to proceed (Bylund et al., 2003; Kishi et al., 2000;Mizuseki et al., 1998a; Penzel et al., 1997). When expressed at high levels, each maintains neural stem cells in a proliferative state upstream of neuronal differentiation genes (Bani-Yaghoub et al., 2006; Ellis et al., 2004; Graham et al., 2003; Li et al., 1998;Wang et al., 2006; Wegner and Stolt, 2005; Zappone et al., 2000). Likewise, Sox11, a member of the SoxC subfamily, is up-regulated as neural stem cells transition to neural progenitor cells, and later maintains neuronal progenitors (Bergsland et al., 2006; Uwanogho et al., 1995;Wegner and Stolt, 2005). Thus, together these Sox genes may function downstream of Foxd4, Gmnn and Zic2 to promote the initial step from neural plate stem cell to neural progenitor cell.

Several studies show that other Zic genes and the Irx genes function in neural progenitors downstream of the SoxB1 genes to promote the onset of $b H L H$ neural differentiation gene expression. Zic1 is required for the expression of SoxD (a member of the SoxG group), which causes ectopic neural masses that express $b H L H$ neural differentiation genes (Mizuseki et al., 1998b), and Zic1 and Zic3 promote the expansion of neural progenitors in the spinal cord and forebrain (Aruga et al., 2002; Nakata et al., 1997; 1998). In Drosophila, Iroquois genes are required for the activation of the proneural $b H L H$ genes (GomezSkarmeta et al., 1996), and in Xenopus the homologous Irx/Xiro genes are expressed just prior to the earliest expressed $b H L H$ neural differentiation genes(Bellefroid et al., 1998). While Irx 


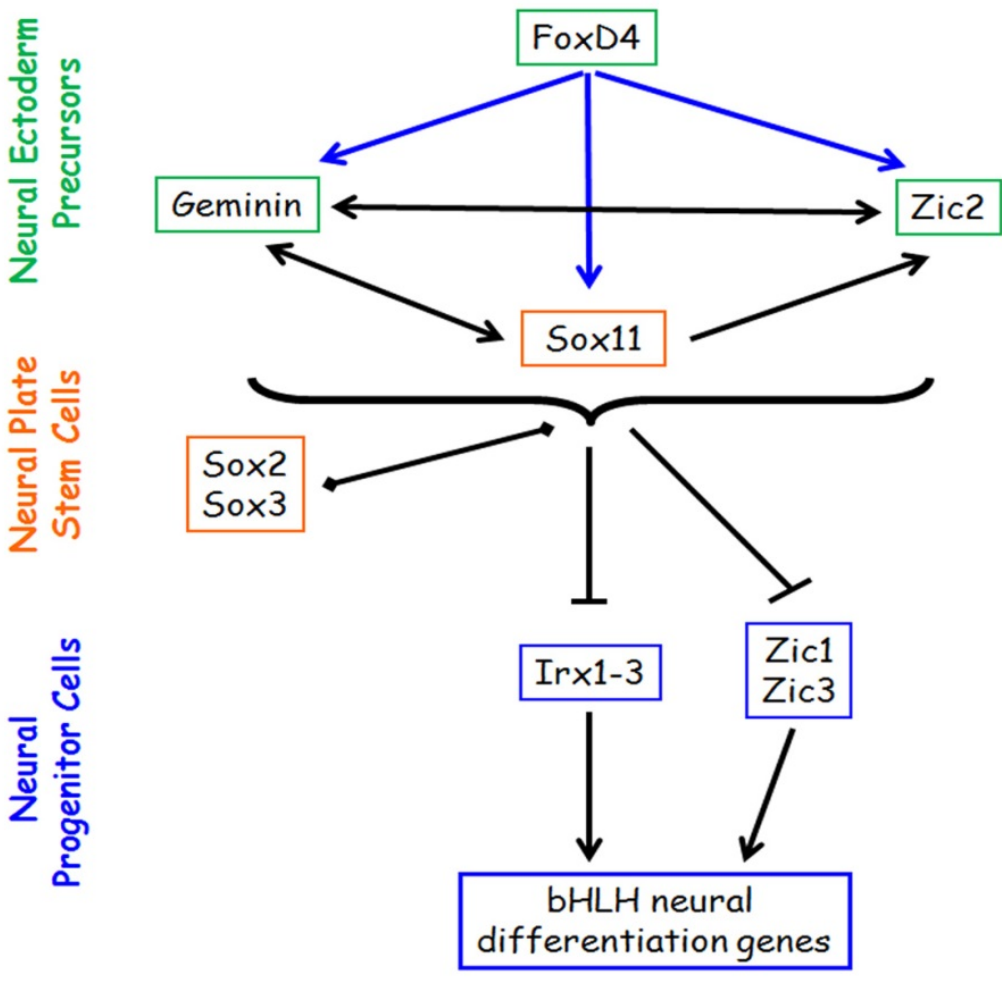

Fig. 2. A gene regulatory network of neural transcription factors that regulate the earliest steps in vertebrate neural development. Foxd4 is required for the expression of the remaining genes, and it directly activates Geminin, Zic2 and Sox11 (blue arrows). Together, these three genes mediate the downstream effects of Foxd4, which is to delay the expression of neural plate stem cell genes (Sox) and repress the expression of neural progenitor genes (Irx, Zic, bHLH). genes promote the onset of neural differentiation (Bellefroid et al., 1998; Gomez-Skarmeta et al., 1998), they also suppress terminal differentiation into neurons (de la Calle-Mustienes et al., 2002).

These studies demonstrate that the nTFs have important roles in maintaining a NE precursor state, regulating the size of the neural plate stem cell population and controlling the onset of differentiation of the neural progenitor cells. However, their functions in cultured stem cells has not been extensively explored. To date, most emphasis has been put on forcing stem cells to a neural fate and then differentiating them into specific neuronal and glial types (Chan et al., 2014; Ross and Akimov, 2014; Wichterle et al., 2002). However, a common problem with these protocols is the difficulty in maintaining neural precursors in an immature, undifferentiated state. For many therapeutic applications this would be advantageous because it would expand neural precursor cells without the spontaneous and premature differentiation that commonly occurs in these cultures. In the embryo, proliferative NE precursors first form from embryonic ectoderm in response to neural inductive signaling. Next, as the neural plates forms, these cells transition into neural plate stem cells which subsequently differentiate into regionally-specified neural progenitor cells. Whereas in the embryo, proliferative, undifferentiated neural precursors can be maintained, it is rare to see this kind of cell in ESC cultures. However, similar primitive neural precursors do form in mouse ESC cultures when neural inductive signaling is maintained either by adding anti-BMP factors or growing cells at a low enough density to dilute endogenously produced BMPs (Tropepe et al., 2001). The molecular mechanisms by which this primitive state is acquired and maintained, and by which these cells transition to the better characterized neural stem cell state will be important to elucidate in light of the potential to eliminate tumor-producing pluripotent cells.
A neural plate gene regulatory network

The studies summarized above took a gene-by-gene approach to understand the functions of each nTF during the progressive transition from neural inductive signaling to neural progenitor differentiation. Based on their sequential and overlapping activities it seems likely that the nTFs coordinately function in a gene regulatory network (Fig. 2). An initial set of nTFs maintains cells in a stable, immature NE precursor state that proliferates to form an appropriately sized neural plate. These are then down-regulated and a different set of nTFs is activated to promote the formation of the neural stem cell constituents of the neural plate. Finally, neural stem cell nTFs are down-regulated and a third set of nTFs is activated that initiate neural differentiation. Our understanding of the functional and transcriptional relationships between these proteins is woefully incomplete, yet this information is fundamental for understanding how the balance between neural precursor, neural stem and neural progenitors is molecularly regulated.

Developmental events often are controlled by regulatory networks of transcription factors that control temporal and regionspecific gene expression (Levine and Davidson, 2005). Therefore, we sought to place these nTFs in a network to determine their distinct roles in the progression from NE precursors to differentiating neural progenitors by analyzing the epistatic position of Foxd4 amongst these other nTFs. Using protein knock-down approaches we found that Foxd4 is required for the expression of each of the other nTFs(Yan et al., 2009), thus placing it upstream in the network (Fig. 2). Using gain-of-function approaches, we found that elevated FoxD4 levels in NE precursors upregulated Gmnn and Zic2, delayed the expression of Sox2, Sox3 and Sox11, which resulted in an expanded neural plate; and down-regulated the Zic and Irx genes that promote neural progenitor differentiation. We also found that Foxd4 expression is down-regulated at early neural plate stages, suggesting that 
its repression is required for NE precursors to progress to neural plate stem cells and to neural progenitors. Additional experiments demonstrated that Gmnn, Zic2 and Sox11 together can mediate the Foxd4 effects on the remaining nTFs(Yan et al., 2009). From these results we can construct a gene regulatory network in which Foxd4 is a critical upstream component. It directly activates a transcriptional triad consisting of Gmnn, Zic2 and Sox11, which in turn regulates the more down-stream components that promote the transition to neural stem and neural progenitor cells (Fig. 2). Finally, structure-function analyses of the Foxd4 protein show that it has separate domains in the $\mathrm{N}$ and C-terminal regions that account for its ability to both activate or repress targets (Klein et al., 2013; Neilson et al., 2012). These findings illustrate how a single transcription factor can regulate the transition of immature, NE precursors to neurally-committed stem cells, and then to neural progenitors that are beginning to differentiate.

The experiments described above demonstrate that Foxd4 is a critical element in the gene regulatory network that regulates the balance between NE precursors, neural plate stem cells and regionally specified neural progenitor cells. Elucidating how these different nTF genes interact to regulate this balance between expanding precursor populations and initiating differentiation should ultimately prove useful for preventing the formation of mesodermal and endodermal cells in neuronal culture protocols, expanding the number of neural precursors available and preventing their premature differentiation.

One would predict from the experiments performed in embryos that during the differentiation of ESCs into NSCs Foxd4, Gmnn, Zic2 and Sox11 would act early to promote immature, proliferative NE precursors and impede neural differentiation (Fig. 2). Our preliminary work analyzing the role of Foxd4 in embryoid bodies derived from mouse ESCs and differentiated along a neural lineage indicates that this protein is key to the transition between pluripotency and neurally committed cells, just as in the embryo (Moody et al., 2013, and unpublished observations). In the embryo, Gmnn promotes an uncommitted state by promoting Polycomb mediated repressive histone marks at differentiationpromoting genes (Lim et al., 2011). It also prevents premature neurogenesis by antagonizing the interaction between Brg and bHLH neural differentiation factors (Seo et al., 2005). Just like in the embryo, in mouse ESCs Gmnn is required for the acquisition of a neural fate, and can promote the formation of neural precursor cells by maintaining the chromatin in a hyper-acetylated state and in an open conformation that allows other nTFs access to their binding sites on the DNA (Yellajoshyula et al., 2011). Subsequent work showed that Gmnn promotes both activating and repressive histone modifications at neural differentiation genes, suggesting that Gmnn makes the chromatin accessible to both factors that promote NE precursors as well as to factors that will subsequently activate neural differentiation genes (Yellajoshyula et al., 2012). These results explain why Gmnndeficient neural progenitors in the mouse cortex are defective in cell proliferation and differentiation (Spella et al., 2011), whereas Gmnn-deficient NSCs in neurospheres can still divide and differentiate into neurons and glia (Schultz et al., 2011).

Whereas the role of Zic2 has not been examined in ESC culture, Sox genes have been extensively studied. SoxB1 family proteins (Sox1, Sox2, Sox3) are expressed throughout mouse and chick embryo NE precursors and neural plate stem cells, and when expressed at high levels they prevent cells from differentiating into neurons (Uwanogho et al., 1995; Wegner, 1999). In addition, Sox2 has an earlier function in ESCs: maintenance of pluripotency(Avilion et al., 2003). Sox11 is expressed through- out NE precursors and neural plate stem cells, overlapping completely with Sox2 and Sox 3 expression in Xenopus (Hyodo-Miura et al., 2002), whereas in chick and mouse embryos, it is expressed later in neural progenitors and differentiating neurons, and does not overlap with Sox2 or Sox3 expression in the neural tube (Uwanogho et al., 1995; Wegner, 1999); in mouse it also is expressed in several other tissues to support progenitor cell survival (Bhattaram et al., 2010). A recent study showed that Sox2, Sox3 and Sox11 bind to the promoters/enhancers of the same neural genes expressed in mouse NSCs, neural progenitors and differentiating neurons in a defined temporal sequence (Bergsland et al., 2011). In ESCs, Sox2 binds to NSC genes to mark sites for later Sox3 binding. Subsequently in NSCs, Sox3 binds to neuronal differentiation genes to mark sites for later Sox11 binding. In each case, Sox protein binding results in bivalent chromatin marks, indicating that part of their effect is making the appropriate neural genes accessible to other transcriptional factors that are expressed later.

\section{Neural progenitor differentiation}

There is a large literature that describes the nTFs that are involved in neural progenitor cell (NPC) formation that has been extensively reviewed elsewhere (Florio and Huttner, 2014; Imayoshi and Kageyama, 2014). As mentioned above, the bHLH factors, particularly NeuroG and NeuroD are critical for NPCs to exit the cell cycle and activate neuron or glial specific genes. In addition, pattern formation genes are important in providing NPCs with their spatial address within the neural tube. Depending upon whether the NPC is located in the anterior or posterior, dorsal or ventral parts of the neural tube, the expression of patterning genes will impact whether it differentiates into the forebrain versus spinal cord, and sensory versus motor neuron.

\section{CONCLUSION}

A large literature describes the signaling and transcriptional factors that are responsible for differentiating neural progenitor cells into the wide range of neurons and glia that are responsible for the complex function of the vertebrate central nervous system. These factors are important for understanding how the brain functions, and for designing stem cell protocols to replace specific cells affected by neurodegenerative disease and injury. In contrast, much less in know about the molecular regulation that guides a newly induced neural ectodermal cell to commit to its new fate, expand the neural plate stem cell population and transition to a neural progenitor cells. As work in the embryo reveals more details about the regulation of these earliest steps in neural development, we need to test these details in cultured stem cell paradigms to facilitate the manipulation of NSCs for therapeutic uses. It is now important to test these possibilities experimentally, and elucidate the essential gene regulatory network in mammalian ESC- and iPSCderived neural cell cultures. Using the information we have obtained from the embryo should greatly facilitate these efforts.

\section{ACKNOWLEDGMENTS}

This work was supported by the Basic Science Research Program through the National Research Foundation of Korea (NRF), funded by the Ministry of Education, Science and Technology (NRF2012R1A1A2042334), by a grant from the Next-Generation BioGreen 21 Program (PJ009564), Rural Development Administration, Republic of Korea, and by grants from the NIH (NS23158) and NSF (MCB1121711). 


\section{REFERENCES}

Ahmed, S., Gan, H.T., Lam, C.S., Poonepalli, A., Ramasamy, S., Tay, Y., Tham, M., and Yu, Y.H. (2009). Transcription factors and neural stem cell self-renewal, growth and differentiation. Cell Adh. Migr. 3, 412-424.

Aruga, J., Tohmonda, T., Homma, S., and Mikoshiba, K. (2002). Zic1 promotes the expansion of dorsal neural progenitors in spinal cord by inhibiting neuronal differentiation. Dev. Biol. 244, 329-341.

Avilion, A.A., Nicolis, S.K., Pevny, L.H., Perez, L., Vivian, N., and Lovell-Badge, R. (2003). Multipotent cell lineages in early mouse development depend on SOX2 function. Genes Dev. 17, 126-140.

Bani-Yaghoub, M., Tremblay, R.G., Lei, J.X., Zhang, D., Zurakowski, B., Sandhu, J.K., Smith, B., Ribecco-Lutkiewicz, M., Kennedy, J., Walker, P.R., et al. (2006). Role of Sox2 in the development of the mouse neocortex. Dev. Biol. 295, 52-66.

Bellefroid, E.J., Kobbe, A., Gruss, P., Pieler, T., Gurdon, J.B., and Papalopulu, N. (1998). Xiro3 encodes a Xenopus homolog of the Drosophila Iroquois genes and functions in neural specification. EMBO J. 17, 191-203.

Bergsland, M., Werme, M., Malewicz, M., Perlmann, T., and Muhr, J. (2006). The establishment of neuronal properties is controlled by Sox4 and Sox11. Genes Dev. 20, 3475-3486.

Bergsland, M., Ramskold, D., Zaouter, C., Klum, S., Sandberg, R., and Muhr, J. (2011). Sequentially acting Sox transcription factors in neural lineage development. Genes Dev. 25, 2453-2464.

Bhattaram, P., Penzo-Mendez, A., Sock, E., Colmenares, C., Kaneko, K.J., Vassilev, A., Depamphilis, M.L., Wegner, M., and Lefebvre, V. (2010). Organogenesis relies on SoxC transcription factors for the survival of neural and mesenchymal progenitors. Nat. Commun. 1, 9.

Brault, V., Moore, R., Kutsch, S., Ishibashi, M., Rowitch, D.H., McMahon, A.P., Sommer, L., Boussadia, O., and Kemler, R. (2001). Inactivation of the beta-catenin gene by Wnt1-Cremediated deletion results in dramatic brain malformation and failure of craniofacial development. Development 128, 1253-1264.

Brewster, R., Lee, J., and Ruiz i Altaba, A. (1998). Gli/Zic factors pattern the neural plate by defining domains of cell differentiation. Nature 393, 579-583.

Bylund, M., Andersson, E., Novitch, B.G., and Muhr, J. (2003). Vertebrate neurogenesis is counteracted by Sox1-3 activity. Nat. Neurosci. 6, 1162-1168.

Chaddah, R., Arntfield, M., Runciman, S., Clarke, L., and van der Kooy, D. (2012). Clonal neural stem cells from human embryonic stem cell colonies. J. Neurosci. 32, 7771-7781.

Chan, T.M., Chen, J.Y., Ho, L.I., Lin, H.P., Hsueh, K.W., Liu, D.D., Chen, Y.H., Hsieh, A.C., Tsai, N.M., Hueng, D.Y., et al. (2014) ADSC therapy in neurodegenerative disorders. Cell Transplant. 23, 549-557.

Chng, Z., Teo, A., Pedersen, R.A., and Vallier, L. (2010). SIP1 mediates cell-fate decisions between neuroectoderm and mesendoderm in human pluripotent stem cells. Cell Stem Cell 6, 59-70.

Collignon, J., Sockanathan, S., Hacker, A., Cohen-Tannoudji, M., Norris, D., Rastan, S., Stevanovic, M., Goodfellow, P.N., and Lovell-Badge, R. (1996). A comparison of the properties of Sox-3 with Sry and two related genes, Sox-1 and Sox-2. Development $122,509-520$.

Dahmane, N., Sanchez, P., Gitton, Y., Palma, V., Sun, T., Beyna, M., Weiner, H., and Ruiz i Altaba, A. (2001). The Sonic Hedgehog-Gl pathway regulates dorsal brain growth and tumorigenesis. Development 128, 5201-5212.

de la Calle-Mustienes, E., Glavic, A., Modolell, J., and GomezSkarmeta, J.L. (2002). Xiro homeoproteins coordinate cell cycle exit and primary neuron formation by upregulating neuronal-fate repressors and downregulating the cell-cycle inhibitor XGadd45gamma. Mech. Dev. 119, 69-80.

De Robertis, E.M., and Kuroda, H. (2004). Dorsal-ventral patterning and neural induction in Xenopus embryos. Ann. Rev. Cell Dev. Biol. 20, 285-308.

Devine, M.J., Ryten, M., Vodicka, P., Thomson, A.J., Burdon, T., Houlden, H., Cavaleri, F., Nagano, M., Drummond, N.J., Taanman, J.W., et al. (2011). Parkinson's disease induced pluripotent stem cells with triplication of the alpha-synuclein locus. Nat. Commun. 2, 440.
Eisaki, A., Kuroda, H., Fukui, A., and Asashima, M. (2000). XSIP1, a member of two-handed zinc finger proteins, induced anterior neural markers in Xenopus laevis animal cap. Biochem. Biophys. Res. Commun. 271, 151-157.

Ellis, P., Fagan, B.M., Magness, S.T., Hutton, S., Taranova, O., Hayashi, S., McMahon, A., Rao, M., and Pevny, L. (2004). SOX2, a persistent marker for multipotential neural stem cells derived from embryonic stem cells, the embryo or the adult. Dev. Neurosci. 26, 148-165.

Florio, M., and Huttner, W.B. (2014). Neural progenitors, neurogenesis and the evolution of the neocortex. Development 141, 21822194.

Fuccillo, M., Joyner, A.L., and Fishell, G. (2006). Morphogen to mitogen: the multiple roles of hedgehog signalling in vertebrate neural development. Nat. Rev. Neurosci. 7, 772-783.

Fujita, S. (2003). The discovery of the matrix cell, the identification of the multipotent neural stem cell and the development of the central nervous system. Cell Struct. Funct. 28, 205-228.

Gaiano, N., Nye, J.S., and Fishell, G. (2000). Radial glial identity is promoted by Notch1 signaling in the murine forebrain. Neuron 26 , 395-404.

Glavic, A., Gomez-Skarmeta, J.L., and Mayor, R. (2001). Xiro-1 controls mesoderm patterning by repressing bmp-4 expression in the Spemann organizer. Dev. Dyn. 222, 368-376.

Gomez-Skarmeta, J.L., Diez del Corral, R., de la Calle-Mustienes, E., Ferre-Marco, D., and Modolell, J. (1996). Araucan and caupolican, two members of the novel iroquois complex, encode homeoproteins that control proneural and vein-forming genes. Cell 85, 95-105.

Gomez-Skarmeta, J.L., Glavic, A., de la Calle-Mustienes, E. Modolell, J., and Mayor, R. (1998). Xiro, a Xenopus homolog of the Drosophila Iroquois complex genes, controls development at the neural plate. EMBO J. 17, 181-190.

Gomez-Skarmeta, J., de La Calle-Mustienes, E., and Modolell, J. (2001). The Wnt-activated Xiro1 gene encodes a repressor that is essential for neural development and downregulates Bmp4. Development 128, 551-560.

Graham, V., Khudyakov, J., Ellis, P., and Pevny, L. (2003). SOX2 functions to maintain neural progenitor identity. Neuron 39, 749765.

Greber, B., Coulon, P., Zhang, M., Moritz, S., Frank, S., MullerMolina, A.J., Arauzo-Bravo, M.J., Han, D.W., Pape, H.C., and Scholer, H.R. (2011). FGF signalling inhibits neural induction in human embryonic stem cells. EMBO J. 30, 4874-4884.

Hatakeyama, J., Bessho, Y., Katoh, K., Ookawara, S., Fujioka, M., Guillemot, F., and Kageyama, R. (2004). Hes genes regulate size, shape and histogenesis of the nervous system by control of the timing of neural stem cell differentiation. Development 131, 55395550 .

Hyodo-Miura, J., Urushiyama, S., Nagai, S., Nishita, M., Ueno, N., and Shibuya, H. (2002). Involvement of NLK and Soxi1 in neural induction in Xenopus development. Genes Cells 7, 487-496.

Imayoshi, I., and Kageyama, R. (2014). bHLH factors in self-renewal, multipotency, and fate choice of neural progenitor cells. Neuron $82,9-23$.

Ishibashi, M., Ang, S.L., Shiota, K., Nakanishi, S., Kageyama, R., and Guillemot, F. (1995). Targeted disruption of mammalian hairy and Enhancer of split homolog-1 (HES-1) leads to up-regulation of neural helix-loop-helix factors, premature neurogenesis, and severe neural tube defects. Genes Dev. 9, 3136-3148.

Itoh, K., and Sokol, S.Y. (2007). Early development of epidermis and neural tissue. In Principles of Developmental Genetics. S.A.Moody,ed., (New York, USA: Elsevier), pp. 241-257.

Kalani, M.Y., Cheshier, S.H., Cord, B.J., Bababeygy, S.R., Vogel, H., Weissman, I.L., Palmer, T.D., and Nusse, R. (2008). Wntmediated self-renewal of neural stem/progenitor cells. Proc. Natl. Acad. Sci. USA 105, 16970-16975.

Kishi, M., Mizuseki, K., Sasai, N., Yamazaki, H., Shiota, K., Nakanishi, S., and Sasai, Y. (2000). Requirement of Sox2-mediated signaling for differentiation of early Xenopus neuroectoderm. Development 127, 791-800.

Klein, S.L., Neilson, K.M., Orban, J., Yaklichkin, S., Hoffbauer, J., Mood, K., Daar, I.O., and Moody, S.A. (2013). Conserved structural domains in FoxD4L1, a neural forkhead box transcription factor, are required to repress or activate target genes. PLoS One $8, \mathrm{e} 61845$. 
Kroll, K.L., Salic, A.N., Evans, L.M., and Kirschner, M.W. (1998) Geminin, a neuralizing molecule that demarcates the future neural plate at the onset of gastrulation. Development 125, 32473258.

Kuo, J.S., Patel, M., Gamse, J., Merzdorf, C., Liu, X., Apekin, V., and Sive, H. (1998). Opl: a zinc finger protein that regulates neural determination and patterning in Xenopus. Development 125 2867-2882.

Levine, M., and Davidson, E.H. (2005). Gene regulatory networks for development. Proc. Natl. Acad. Sci. USA 102, 4936-4942.

Levine, A.J., and Brivanlou, A.H. (2007). Proposal of a model of mammalian neural induction. Dev. Biol. 308, 247-256.

Li, M., Pevny, L., Lovell-Badge, R., and Smith, A. (1998). Generation of purified neural precursors from embryonic stem cells by lineage selection. Curr. Biol. 8, 971-974.

Lim, J.W., Hummert, P., Mills, J.C., and Kroll, K.L. (2011). Geminin cooperates with Polycomb to restrain multi-lineage commitment in the early embryo. Development $138,33-44$.

Miyagi, S., Masui, S., Niwa, H., Saito, T., Shimazaki, T., Okano, H. Nishimoto, M., Muramatsu, M., Iwama, A., and Okuda, A. (2008) Consequence of the loss of Sox2 in the developing brain of the mouse. FEBS Lett. 582, 2811-2815.

Mizuseki, K., Kishi, M., Matsui, M., Nakanishi, S., and Sasai, Y. (1998a). Xenopus Zic-related-1 and Sox-2, two factors induced by chordin, have distinct activities in the initiation of neural induction. Development 125, 579-587.

Mizuseki, K., Kishi, M., Shiota, K., Nakanishi, S., and Sasai, Y. (1998b). SoxD: an essential mediator of induction of anterior neural tissues in Xenopus embryos. Neuron 21, 77-85.

Mizutani, K., Yoon, K., Dang, L., Tokunaga, A., and Gaiano, N. (2007). Differential Notch signalling distinguishes neural stem cells from intermediate progenitors. Nature 449, 351-355.

Molofsky, A.V., He, S., Bydon, M., Morrison, S.J., and Pardal, R. (2005). Bmi-1 promotes neural stem cell self-renewal and neural development but not mouse growth and survival by repressing the p16Ink4a and p19Arf senescence pathways. Genes Dev. 19, 1432-1437.

Moody, S.A., Klein, S.L., Karpinski, B.A., Maynard, T.M., and Lamantia, A.S. (2013). On becoming neural: what the embryo can tell us about differentiating neural stem cells. Am. J. Stem Cells 2, 74-94

Nakata, K., Nagai, T., Aruga, J., and Mikoshiba, K. (1997). Xenopus Zic3, a primary regulator both in neural and neural crest development. Proc. Natl. Acad. Sci. USA 94, 11980-11985.

Nakata, K., Nagai, T., Aruga, J., and Mikoshiba, K. (1998). Xenopus Zic family and its role in neural and neural crest development. Mech. Dev. 75, 43-51.

Neely, M.D., Litt, M.J., Tidball, A.M., Li, G.G., Aboud, A.A., Hopkins, C.R., Chamberlin, R., Hong, C.C., Ess, K.C., and Bowman, A.B. (2012). DMH1, a highly selective small molecule BMP inhibito promotes neurogenesis of hiPSCs: comparison of PAX6 and SOX1 expression during neural induction. ACS Chem. Neurosci. 3, 482-491.

Neilson, K.M., Klein, S.L., Mhaske, P., Mood, K., Daar, I.O., and Moody, S.A. (2012). Specific domains of FoxD4/5 activate and repress neural transcription factor genes to control the progression of immature neural ectoderm to differentiating neural plate. Dev. Biol. 365, 363-375.

Nitta, K.R., Tanegashima, K., Takahashi, S., and Asashima, M. (2004). XSIP1 is essential for early neural gene expression and neural differentiation by suppression of BMP signaling. Dev. Biol. $275,258-267$.

Nitta, K.R., Takahashi, S., Haramoto, Y., Fukuda, M., Tanegashima, K., Onuma, Y., and Asashima, M. (2007). The N-terminus zinc finger domain of Xenopus SIP1 is important for neural induction, but not for suppression of Xbra expression. Int. J. Dev. Biol. 51, 321-325.

Ohtsuka, T., Sakamoto, M., Guillemot, F., and Kageyama, R. (2001). Roles of the basic helix-loop-helix genes Hes1 and Hes5 in expansion of neural stem cells of the developing brain. J. Biol. Chem. 276, 30467-30474

Palma, V., and Ruiz i Altaba, A. (2004). Hedgehog-GLI signaling regulates the behavior of cells with stem cell properties in the developing neocortex. Development 131, 337-345.

Penzel, R., Oschwald, R., Chen, Y., Tacke, L., and Grunz, H. (1997). Characterization and early embryonic expression of a neura specific transcription factor XSOX3 in Xenopus laevisInt. J. Dev. Biol. 41, 667-677.

Rogers, C.D., Archer, T.C., Cunningham, D.D., Grammer, T.C., and Casey, E.M. (2008). Sox3 expression is maintained by FGF signaling and restricted to the neural plate by Vent proteins in the Xenopus embryo. Dev. Biol. 313, 307-319.

Rogers, C.D., Moody, S.A., and Casey, E.S. (2009a). Neural induction and factors that stabilize a neural fate.Birth Defects Res. C Embryo Today 87, 249-262.

Rogers, C.D., Harafuji, N., Archer, T., Cunningham, D.D., and Casey, E.S. (2009b). Xenopus Sox3 activates sox2 and geminin and indirectly represses Xvent2 expression to induce neural progenitor formation at the expense of non-neural ectodermal derivatives. Mech. Dev. 126, 42-55

Ross, C.A., and Akimov, S.S. (2014). Human-induced pluripotent stem cells: potential for neurodegenerative diseases. Hum. Mol. Genet.[Epub ahead of print].

Sasai, Y. (1998). Identifying the missing links: genes that connect neural induction and primary neurogenesis in vertebrate embryos. Neuron 21, 455-458.

Schultz, K.M., Banisadr, G., Lastra, R.O., McGuire, T., Kessler, J.A. Miller, R.J., and McGarry, T.J. (2011). Geminin-deficient neural stem cells exhibit normal cell division and normal neurogenesis. PLoS One 6, e17736.

Seo, S., and Kroll, K.L. (2006). Geminin's double life: chromatin connections that regulate transcription at the transition from proliferation to differentiation. Cell Cycle 5, 374-379.

Seo, S., Herr, A., Lim, J.W., Richardson, G.A., Richardson, H., and Kroll, K.L. (2005). Geminin regulates neuronal differentiation by antagonizing Brg1 activity. Genes Dev. 19, 1723-1734.

Sheng, G., dos Reis, M., and Stern, C.D. (2003). Churchill, a zinc finger transcriptional activator, regulates the transition between gastrulation and neurulation. Cell 115, 603-613.

Snir, M., Ofir, R., Elias, S., and Frank, D. (2006). Xenopus laevis POU91 protein, an Oct3/4 homologue, regulates competence transitions from mesoderm to neural cell fates. EMBO J. 25, 3664-3674.

Spella, M., Kyrousi, C., Kritikou, E., Stathopoulou, A., Guillemot, F., Kioussis, D., Pachnis, V., Lygerou, Z., and Taraviras, S. (2011). Geminin regulates cortical progenitor proliferation and differentiation. Stem Cells 29, 1269-1282.

Spemann, H., and Mangold, H. (2001). Induction of embryonic primordia by implantation of organizers from a different species. 1923. Int. J. Dev. Biol. 45, 13-38.

Stern, C.D. (2005). Neural induction: old problem, new findings, yet more questions. Development 132, 2007-2021.

Streit, A., Lee, K.J., Woo, I., Roberts, C., Jessell, T.M., and Stern, C.D. (1998). Chordin regulates primitive streak development and the stability of induced neural cells, but is not sufficient for neural induction in the chick embryo. Development 125, 507-519.

Streit, A., Berliner, A.J., Papanayotou, C., Sirulnik, A., and Stern, C.D. (2000). Initiation of neural induction by FGF signalling before gastrulation. Nature 406, 74-78.

Sullivan, S.A., Akers, L., and Moody, S.A. (2001). foxD5a, a Xenopus winged helix gene, maintains an immature neural ectoderm via transcriptional repression that is dependent on the C-terminal domain. Dev. Biol. 232, 439-457.

Sun, G., Yu, R.T., Evans, R.M., and Shi, Y. (2007). Orphan nuclear receptor TLX recruits histone deacetylases to repress transcription and regulate neural stem cell proliferation. Proc. Natl. Acad. Sci. USA 104, 15282-15287.

Taylor, J.J., Wang, T., and Kroll, K.L. (2006). Tcf- and Vent-binding sites regulate neural-specific geminin expression in the gastrula embryo. Dev. Biol. 289, 494-506.

Tropepe, V., Hitoshi, S., Sirard, C., Mak, T.W., Rossant, J., and van der Kooy, D. (2001). Direct neural fate specification from embryonic stem cells: a primitive mammalian neural stem cell stage acquired through a default mechanism. Neuron 30, 65-78

Uwanogho, D., Rex, M., Cartwright, E.J., Pearl, G., Healy, C., Scotting, P.J., and Sharpe, P.T. (1995). Embryonic expression of the chicken Sox2, Sox 3 and Sox11 genes suggests an interactive role in neuronal development. Mech. Dev. 49, 23-36.

Verschueren, K., Remacle, J.E., Collart, C., Kraft, H., Baker, B.S. Tylzanowski, P., Nelles, L., Wuytens, G., Su, M.T., Bodmer, R., et al. (1999). SIP1, a novel zinc finger/homeodomain repressor, interacts with Smad proteins and binds to $5^{\prime}$-CACCT sequences in 
candidate target genes. J. Biol. Chem. 274, 20489-20498.

Wang, T.W., Stromberg, G.P., Whitney, J.T., Brower, N.W. Klymkowsky, M.W., and Parent, J.M. (2006). Sox3 expression identifies neural progenitors in persistent neonatal and adult mouse forebrain germinative zones. J. Comp. Neurol. 497, 88100.

Wegner, M. (1999). From head to toes: the multiple facets of Sox proteins. Nucleic Acids Res. 27, 1409-1420.

Wegner, M., and Stolt, C.C. (2005). From stem cells to neurons and glia: a Soxist's view of neural development. Trends Neurosci. 28 , 583-588.

Wichterle, H., Lieberam, I., Porter, J.A., and Jessell, T.M. (2002) Directed differentiation of embryonic stem cells into motor neurons. Cell 110, 385-397.

Wilson, S.I., Graziano, E., Harland, R., Jessell, T.M., and Edlund, T. (2000). An early requirement for FGF signalling in the acquisition of neural cell fate in the chick embryo. Curr. Biol. 10, 421-429.

Wood, H.B., and Episkopou, V. (1999). Comparative expression of the mouse Sox1, Sox2 and Sox3 genes from pre-gastrulation to early somite stages. Mech. Dev. 86, 197-201.

Yan, B., Neilson, K.M., and Moody, S.A. (2009). foxD5 plays a critica upstream role in regulating neural ectodermal fate and the onset of neural differentiation. Dev. Biol. 329, 80-95.
Yan, B., Neilson, K.M., and Moody, S.A. (2010). Microarray identification of novel downstream targets of FoxD4L1/D5, a critical component of the neural ectodermal transcriptional network. Dev. Dyn. 239, 3467-3480.

Yellajoshyula, D., Patterson, E.S., Elitt, M.S., and Kroll, K.L. (2011) Geminin promotes neural fate acquisition of embryonic stem cells by maintaining chromatin in an accessible and hyperacetylated state. Proc. Natl. Acad. Sci. USA 108, 3294-3299.

Yellajoshyula, D., Lim, J.W., Thompson, D.M., Jr., Witt, J.S., Patterson, E.S., and Kroll, K.L. (2012). Geminin regulates the transcriptional and epigenetic status of neuronal fate-promoting genes during mammalian neurogenesis. Mol. Cell. Biol. 32, 4549-4560.

Zappone, M.V., Galli, R., Catena, R., Meani, N., De Biasi, S., Mattei, E., Tiveron, C., Vescovi, A.L., Lovell-Badge, R., Ottolenghi, S., et al. (2000). Sox2 regulatory sequences direct expression of a (beta)-geo transgene to telencephalic neural stem cells and precursors of the mouse embryo, revealing regionalization of gene expression in CNS stem cells. Development 127, 2367-2382.

Zechner, D., Fujita, Y., Hulsken, J., Muller, T., Walther, I., Taketo, M.M., Crenshaw, E.B., 3rd, Birchmeier, W., and Birchmeier, C. (2003). beta-Catenin signals regulate cell growth and the balance between progenitor cell expansion and differentiation in the nervous system. Dev. Biol. 258, 406-418. 